\title{
Differentiation of human induced pluripotent stem cells into erythroid cells
}

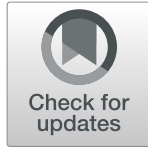

Mohsen Ebrahimi ${ }^{1}$, Mehdi Forouzesh ${ }^{2}$, Setareh Raoufi ${ }^{3}$, Mohammad Ramazii ${ }^{4}$, Farhoodeh Ghaedrahmati ${ }^{5}$ and Maryam Farzaneh $^{6^{*}}$ (D)

\begin{abstract}
During the last years, several strategies have been made to obtain mature erythrocytes or red blood cells (RBC) from the bone marrow or umbilical cord blood (UCB). However, UCB-derived hematopoietic stem cells (HSC) are a limited source and in vitro large-scale expansion of RBC from HSC remains problematic. One promising alternative can be human pluripotent stem cells (PSCS) that provide an unlimited source of cells. Human PSCs, including embryonic stem cells (ESCs) and induced pluripotent stem cells (iPSCs), are self-renewing progenitors that can be differentiated to lineages of ectoderm, mesoderm, and endoderm. Several previous studies have revealed that human ESCs can differentiate into functional oxygen-carrying erythrocytes; however, the ex vivo expansion of human ESC-derived RBC is subjected to ethical concerns. Human iPSCs can be a suitable therapeutic choice for the in vitro/ex vivo manufacture of RBCs. Reprogramming of human somatic cells through the ectopic expression of the transcription factors (OCT4, SOX2, KLF4, c-MYC, LIN28, and NANOG) has provided a new avenue for disease modeling and regenerative medicine. Various techniques have been developed to generate enucleated RBCs from human iPSCs. The in vitro production of human iPSC-derived RBCs can be an alternative treatment option for patients with blood disorders. In this review, we focused on the generation of human iPSC-derived erythrocytes to present an overview of the current status and applications of this field.
\end{abstract}

Keywords: Induced pluripotent stem cells, Erythrocytes, Reprogramming, Differentiation, Large-scale, Blood disorders

\section{Introduction}

Blood transfusion is the main therapeutic option and a crucial part of modern medicine for patients with severe anemia [1, 2]. A limited resource of blood, blood group compatibility ( $\mathrm{ABO}$ and $\mathrm{Rh}$ antigens), and the risks of infection can present great challenges for blood transfusion $[2,3]$. Therefore, any alternative solution methods would be most helpful for patients with rare blood groups [4]. Mature red blood cells (RBCs) or erythrocytes/erythroid cells in a complex process called erythropoiesis are produced from hematopoietic stem cells

\footnotetext{
* Correspondence: Maryamfarzaneh2013@yahoo.com

${ }^{6}$ Physiology Research Center, Ahvaz Jundishapur University of Medical Sciences, Ahvaz, Iran

Full list of author information is available at the end of the article
}

(HSCs) [5-7]. Erythroblasts (precursors of RBCs) are difficult to proliferate in vitro $[2,8,9]$. In past decades, several groups have generated erythrocytes from umbilical cord blood (UCB)-derived HSCs [2, 10]. Although multipotent HSCs have the capacity for self-renewal, the large-scale in vitro/ex vivo HSCs expansion and differentiation into RBCs is a difficult task [2, 11, 12]. Ex vivo cultured RBCs can also be obtained from immortalized erythroid precursors and pluripotent stem cells (PSCs) $[13,14]$. Human PSCs including embryonic stem cells (ESCs) and induced pluripotent stem cells (iPSCs) have the potential to proliferate indefinitely in culture and give rise to lineages of ectoderm, mesoderm, and endoderm [15-17]. Therefore, much attention has focused on human PSCs to replace current transfusion banking [18, 
19]. Several previous studies have revealed that human ESCs can differentiate into functional oxygen-carrying erythrocytes with normal function [18, 20, 21]. Unfortunately, the ex vivo expansion of human ESC-derived $\mathrm{RBC}$ is ethically and politically controversial [22, 23]. In contrast, human iPSCs have less ethical and social issues compared to human ESCs [24, 25]. Human iPSCs are produced by the manipulation of differentiated somatic cells [26-29]. Reprogramming of human somatic cells through the ectopic expression of transcription factors has provided a new avenue for disease modeling and regenerative medicine $[16,30]$. As human iPSCs have similar properties with human ESCs, these cells can be a suitable therapeutic choice for the in vitro/ex vivo manufacture of RBCs to eliminate blood supply shortages [31, 32]. Various techniques have been developed to generate enucleated RBCs from human iPSCs [31, 33, 34]. Genome editing and human iPSCs technology has greatly accelerated the use of autologous transfusion therapies [35-38]. In this review, we focused on the generation of human iPSC-derived erythrocytes to present an overview of the current status and applications of this field.

\section{In vivo and in vitro erythropoiesis}

Erythropoiesis is a complex process in the bone marrow in which HSCs proliferate and give rise to erythroid committed progenitors (EPC) and mature RBCs [39, 40]. Following differentiation toward the erythroid lineage, HSCs lose their self-renewal properties and become restricted to generate burst-forming unit (BFU-E), colonyforming unit-erythroid (CFU-E), basophilic (BasoE), polychromatophilic (PolyE), orthochromatic erythroblasts (OrthoE), reticulocytes (Retic), and RBCs [8] (Fig. 1). This developmental procedure is controlled by cell-cell/cellmatrix interactions along with several cytokines and growth factors including IL-3, IL-6, erythropoietin (EPO) (the main erythropoietic stimulating hormone), EPOreceptor, members of the transforming growth factor- $\beta$ (TGF- $\beta$ ), activin A, activin receptor-II, Flt3 ligand (Flt3-L), vascular endothelial growth factor (VEGF), stem cell factor (SCF), thrombopoietin (TPO), and granulocyte colony-stimulating factor (G-CSF) [26, 41, 42]. Erythropoiesis is controlled and characterized via multiple transcriptional regulators, including myb, Sox6, Bcl11A, Gata1, and Klf1 [43, 44].

Up to date, several culture systems have been established to obtain a sufficient number of mature and functional RBCs in vitro [8]. Three culture systems including erythroid cells lines (the murine erythroleukemia cell line and the human K562 cell line), HSCs derived from peripheral blood (PB) and UCB, and stem cells (human ESCs, neonatal cord blood (CB), mesenchymal stem cells (MSCs), and human iPSCs) have been evaluated to obtain RBCs [26, 45]. An immortalized or continuous cell lines have a homogenous karyotype that can be altered following continuous cell culture, which might not be the most appropriate for pre-clinical studies or clinical applications [46]. In contrast, human PSCsderived RBCs can be achieved in larger scale cultures $[47,48]$. Many attempts have been made previously to establish all blood lineages, including lymphocytes, megakaryocytes, neutrophils, and RBCs from human ESCs [49-52]. Kaufman et al. for the first time revealed that human ESCs on the murine bone marrow cell line or a yolk sac endothelial cell line could give rise to erythroid cells [53]. Similar results were investigated by other lab using human fetal liver cells to improve the yield of human ESCs-derived erythroid cells [54]. However, the use of human ESCs has faced several challenges, including the host immune response toward ESCs and the ethical issues associated with the destruction of human embryos [55]. Differentiation of mouse iPSCs to blood cells has been investigated less intensively compared to the ESCs $[56,57]$. Recently, human iPSCs have been studied as one of the potential sources for HSCs and RBCs [58-60].

\section{In vitro culture of human iPSC-derived RBCs}

In 2006, murine iPSCs for the first time were obtained from somatic cells by using four transcription factors, Oct4/Klf4/Sox2/c-Myc [61]. In 2007, human iPSCs were generated from primary human fibroblasts using Oct4/ Klf4/Sox2/LIN28 [62]. Human iPSCs enable researchers to generate PSCs using well-defined and highly reproducible protocols [63-65].

Although HSCs can be used for the treatment of hematological disorders [66, 67], the bone marrow biopsy is an invasive procedure with chronic graftversus-host diseases (GVHD), morbidity, and mortality in patients who received allogeneic HSC therapy [68, 69]. Autologous HSCs are an alternative option with a lower mortality rate, though in some cases, genetic correction is necessary before autologous HSCs transplantation [70-72]. However, in vitro expansion of HSCs is one of the main hurdles of autologous HSCs [73, 74]. These limitations can be solved with a renewable source of cells. Human iPSCs as unlimited supplies of autologous cells can be an ideal candidate for genetic correction, differentiation to healthy HSCs, and autologous transplantation $[67,75]$.

More recently, established iPSCs from human fibroblast cells represent a powerful tool for the investigation of early hematopoiesis $[59,76,77]$. One of the promising strategies for the use of iPSC is their capacity to differentiate into RBCs and to eliminate the allogeneic blood shortages [78, 79]. Two approaches including embryoid body (EB) formation (feeder-free culture) and co-culture 


\section{In vivo erythropoiesis}

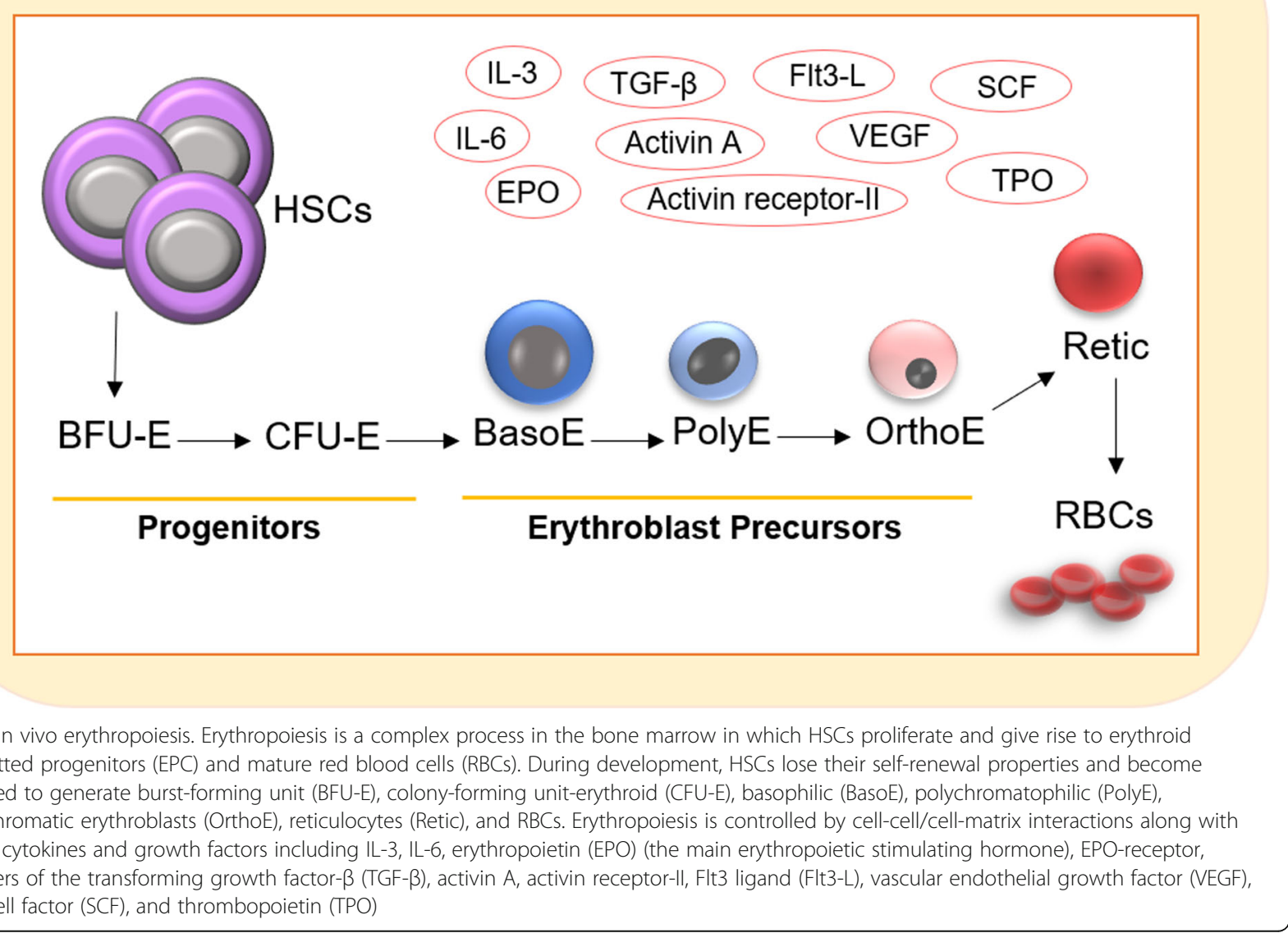

of human iPSCs with feeder cells have been employed for the generation of HSCs from human iPSCs. Many studies have aimed to differentiate human iPSCs into RBCs using EB formation [31, 33, 34]. In general, there are three steps for differentiation of iPSCs into RBCs, including the generation of iPSCs, HSCs, and mature RBCs [33, 80] (Fig. 2). Many attempts have been made previously to achieve human iPSC-derived RBCs under conventional culture methods with SCF, EPO, VEGF, insulin-like growth factor I (IGF-1), dexamethasone (glucocorticoid receptor agonist), ITS (insulin, transferrin, and selenium), TPO, FLT3, BMP4, IL-3, IL-6, and EPO (Table 1). However, an ideal culture condition for human iPSC-derived RBCs should be able to generate large numbers of functional enucleated erythrocytes [31, 86]. Feeder cells as a major cellular component have been found to enhance hematopoiesis from human iPSCs $[81,82]$. It has been shown that OP9 feeder cells as a mouse bone marrow stromal cell line may enhance the hematopoietic differentiation of human iPSCs [86]. Also, C3H10T1/2 feeder cells have the capacity to stimulate the hematopoietic differentiation of human iPSCs $[38,87]$. Increasing in vitro evidence indicates that the cell type of origin and an epigenetic memory for iPSCs may influence on the hematopoietic differentiation of human iPSCs [34, 88, 89]. Compared with iPSC-derived fibroblast cells, the human CD34+ hematopoietic population with the features of MSCs might be more suitable for the hematopoietic differentiation of iPSCs [81]. Following differentiation, HSCs lose their repopulation capacity. Hence, CD34+ HPCs must be purified before starting the differentiation [38]. Human iPSC-derived CD43+ hematopoietic cells have a strongly glycosylated transmembrane sialomucin that can be a suitable option for in vitro erythropoiesis [79]. In HSCs, reactive oxygen species (ROS) can modulate a balance between proliferation and differentiation. In the early stage of hematopoietic differentiation, mitochondria and NADPH oxidases (NOX) are the main sources of ROS [90, 91]. NOX4 as the major NOX enzyme have been shown to play a significant role in the early stages of hematopoietic 


\section{In vitro differentiation of human iPSCs into erythroid cells}

\section{Isolation and cultivation of somatic cells}

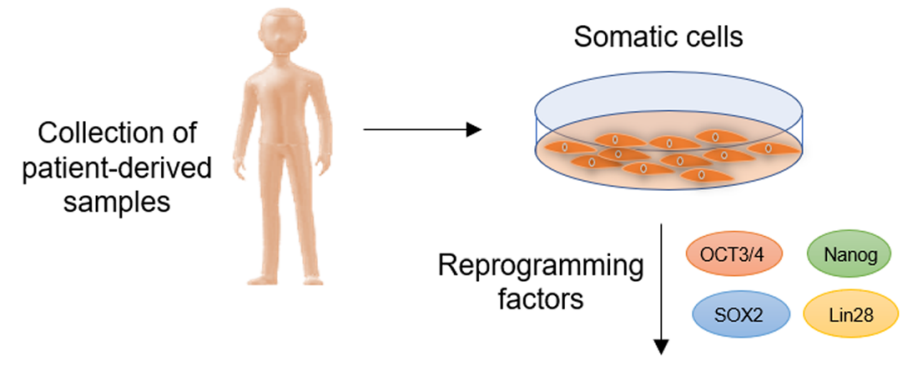

\section{Reprogramming to pluripotency}

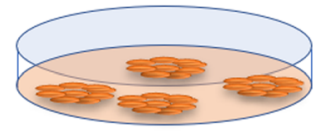

Induced pluripotent stem cells (iPSCs)

\section{Hematopoietic differentiation of iPSCs}

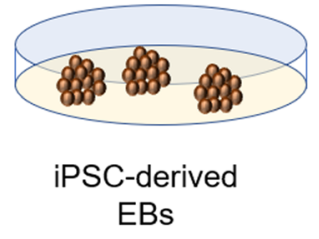

Step I medium (D0-D3) Stemline II, ITS $20 \mathrm{ng} / \mathrm{ml}$ BMP4 $5 \mathrm{ng} / \mathrm{ml}$ Activin A $5 \mathrm{ng} / \mathrm{ml}$ bFGF

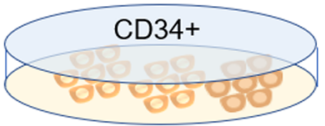

Hematopoietic stem cells (HSCs)

Step II medium (D4-D5) Stemline II, ITS $40 \mathrm{ng} / \mathrm{ml}$ VEGF165 $50 \mathrm{ng} / \mathrm{ml} \mathrm{SCF}$ $5 \mathrm{ng} / \mathrm{ml} \mathrm{bFGF}$

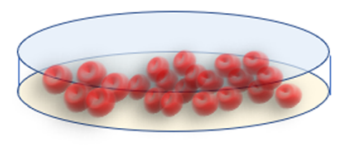

Erythroid cells

Step III medium (D6-D14)

Stemline II, ITS

$50 \mathrm{ng} / \mathrm{ml} \mathrm{SCF}$

$50 \mathrm{ng} / \mathrm{ml}$ Flt3-ligand

$10 \mathrm{ng} / \mathrm{ml}$ TPO

$50 \mathrm{ng} / \mathrm{ml} \mathrm{IL-3}$

$50 \mathrm{ng} / \mathrm{ml} \mathrm{IL-6}$

$5 \mathrm{ng} / \mathrm{ml}$ bFGF

Fig. 2 Differentiation of human iPSCs into RBCs. Human iPSCs can be produced from primary human fibroblasts using Oct4/KIf4/Sox2/LIN28. There are three steps for differentiation of iPSCs into RBCs, including the generation of human PPSCs, HSCs, and RBCs. Several growth factors and cytokines, including SCF, EPO, VEGF, IGF-1, ITS (insulin, transferrin, selenium), dexamethasone (glucocorticoid receptor agonist), TPO, FLT3, BMP4, IL-3, IL-6, and EPO have various functions on human iPSCs differentiation to the erythroid lineage

differentiation from iPSCs [85]. UM171 is a potent small molecule (HSC self-renewal agonist) that increases the derivation of HSPCs from human iPSCs in vitro $[84,92]$. Choi et al. found some variations in the efficiency of human iPSCs differentiation into RBCs. While the pattern of hematopoietic differentiation was similar in seven tested lines [81], Dorn et al. reported that all human iPSCs could give rise to enucleated reticulocytes. But, the growth rate of erythroid cells from iPSC-derived CD34+ HSCs was slightly higher [34]. Uchida et al. demonstrated that compared to the yield of erythroid cells from $\mathrm{PB}$ erythroid progenitor-derived iPSCs, MSC-derived iPSCs produced more efficient definitive erythroid cells with higher bglobin expression [48]. Lapillonne et al. for the first time reported the complete differentiation of human iPSCs into definitive erythrocytes and RBCs with fetal hemoglobin [33]. Dias et al. revealed that the episomal reprogramming or transgene-free human iPSCs can be used for large-scale expansion of human iPSC-derived RBCs [82]. Olivier et al. 
Table 1 In vitro differentiation of human induced pluripotent stem cells (iPSCs) into red blood cells (RBCs)

\begin{tabular}{|c|c|c|c|c|c|}
\hline $\begin{array}{l}\text { Human iPSC cell } \\
\text { source }\end{array}$ & $\begin{array}{l}\text { Reprogramming } \\
\text { transcription factors }\end{array}$ & $\begin{array}{l}\text { Cluster of differentiation (CD) } \\
\text { markers }\end{array}$ & iPSC culture condition & Results & Refs. \\
\hline IMR90 & $\begin{array}{l}\text { POU5F1, SOX2, and } \\
\text { NANOG }\end{array}$ & \multirow{3}{*}{$\begin{array}{l}\text { CD34+ and CD43+ } \\
\text { (hematopoietic progenitors), } \\
\text { CD31+ and CD43- (endothelial } \\
\text { cells), CD43+, CD235at, and } \\
\text { CD41a+/- (erythro- } \\
\text { megakaryopoietic) }\end{array}$} & \multirow{3}{*}{$\begin{array}{l}\text { a-MEM with 20\% defined FBS, } \\
100 \mathrm{ng} / \mathrm{mL} \text { bFGF, OP9 feeder } \\
\text { layer }\end{array}$} & \multirow{3}{*}{$\begin{array}{l}\text { Seven human iPSC lines } \\
\text { could differentiate into } \\
\text { RBCs with the similar } \\
\text { pattern of differentiation }\end{array}$} & \multirow[t]{3}{*}{ [81] } \\
\hline $\begin{array}{l}\text { Fetal and newborn } \\
\text { foreskin fibroblasts }\end{array}$ & $\begin{array}{l}\text { POU5F1, SOX2, } \\
\text { NANOG, and LIN28 }\end{array}$ & & & & \\
\hline Adult skin fibroblasts & $\begin{array}{l}\text { POU5F1, SOX2, and } \\
\text { NANOG (M3-6) or } \\
\text { POU5F1, SOX2, } \\
\text { NANOG, and LIN28 }\end{array}$ & & & & \\
\hline IMR90 and FD-136 & $\begin{array}{l}\text { pSin-EF2-Oct4-Pur, } \\
\text { pSin-EF2-Sox2-Pur, } \\
\text { pSin-EF2-Nanog-Pur } \\
\text { and pSin-EF2-Lin28- } \\
\text { Pur13 }\end{array}$ & $\begin{array}{l}\text { CD34 and/or CD45 } \\
\text { (hematopoietic progenitors), } \\
\text { CD36 and CD235a (erythroid } \\
\text { cells), CD71 (transferrin receptor), } \\
\text { CD45, CD34, and CD71 } \\
\text { (hematopoietic and erythroid } \\
\text { cells) }\end{array}$ & $\begin{array}{l}\text { EB formation on a cellular stroma } \\
100 \mathrm{ng} / \mathrm{mL} \mathrm{SCF}, 100 \mathrm{ng} / \mathrm{mL} \mathrm{TPO} \text {, } \\
100 \mathrm{ng} / \mathrm{mL} \mathrm{FL}, 10 \mathrm{ng} / \mathrm{mL} \mathrm{BMP} 4,5 \\
\mathrm{ng} / \mathrm{mL} \text { VEGF, } 5 \mathrm{ng} / \mathrm{mL} \mathrm{IL}-3,5 \mathrm{ng} / \\
\mathrm{mL} \mathrm{IL}-6,3 \mathrm{U} / \mathrm{mL} \text { Epo, } 10 \mu \mathrm{gg} / \mathrm{mL} \\
\text { insulin, } 3 \mathrm{U} / \mathrm{mL} \text { heparin }\end{array}$ & $\begin{array}{l}\text { The complete } \\
\text { differentiation of human } \\
\text { iPSCs into definitive } \\
\text { erythrocytes and RBCs } \\
\text { with fetal hemoglobin }\end{array}$ & [33] \\
\hline $\begin{array}{l}\text { Human adult and } \\
\text { fetal fibroblasts }\end{array}$ & $\begin{array}{l}\text { POU5F1, SOX2, and } \\
\text { NANOG }\end{array}$ & \multirow{2}{*}{$\begin{array}{l}\text { CD235a+ and CD45- (leukocyte- } \\
\text { free RBCs), CD34+ or CD31+ } \\
\text { (erythroid cells) }\end{array}$} & \multirow{2}{*}{$\begin{array}{l}100 \mathrm{ng} / \mathrm{mL} \text { ZbFGF, OP9 feeder } \\
\text { layer, serum free medium, SCF, } \\
\text { G-CSF, GM-CSF, IL3, IL6 }\end{array}$} & \multirow{2}{*}{$\begin{array}{l}\text { The episomal } \\
\text { reprogramming or } \\
\text { transgene-free human } \\
\text { iPSCs for large-scale ex- }\end{array}$} & \multirow[t]{2}{*}{ [82] } \\
\hline Neonatal fibroblasts & $\begin{array}{l}\text { Episomal vectors that } \\
\text { express OCT4, SOX2, }\end{array}$ & & & & \\
\hline
\end{tabular}

Human cord blood NANOG, LIN28, MYC, $\mathrm{KLF} 4$, and LT

\section{OCT4 and SOX2} or expressing OCT4, $\mathrm{SOX} 2, \mathrm{KLF} 4$, and CMYC (CD34-4F-iPSC) iPs line (33D6), iPSC lines from fibroblast cells (blood group O RhD2), and peripheral blood

Cord blood CD34+ cells

PBMCs or MSCs from SCD patients
OCT4, SOX2, KLF4, and C-Myc

Oct4, KIf4, Sox2, and c-Myc
Human urine
OCT4, SOX2, KLF4, and MYC
CD34+ (iPSCs), CD45+/CD34+ (HSCs), CD45+/CD34- (myeloid precursors), GPA+/CD45(erythroid cells), CD36 and CD71 (primitive erythroid cells)

CD144+/CD31+ (endothelial cells), CD31, CD34, CD36, CD41a,
CD43+ (hematopoietic progenitors), CD36, CD235a, CD45, CD71 (hematopoietic markers), CD31, CD144, CD41a, CD309, and CD4

CD36+/CD71+ (peripheral blood erythroid progenitors (EP)), CD31, CD34, CD41a, CD43, CD45, CD71, CD73, CD144, CD235a, CD309
$10 \%$ human plasma, $10 \mu \mathrm{g} / \mathrm{mL}$ insulin, $330 \mu \mathrm{g} / \mathrm{mL}$ human holotransferrin, $100 \mathrm{ng} / \mathrm{mL}$ SCF, $100 \mathrm{ng} / \mathrm{mL}$ TPO, $100 \mathrm{ng} / \mathrm{mL}$ Flt3$\mathrm{L}, 5 \mathrm{ng} / \mathrm{mL} \mathrm{IL}-3,5 \mathrm{ng} / \mathrm{mL} \mathrm{IL}-6,5$ $\mathrm{ng} / \mathrm{mL}$ VEGF, $10-20 \mathrm{ng} / \mathrm{mL}$ BMP4 $3 \mathrm{U} / \mathrm{mL}$ EPO

Stemline II medium, $20 \mathrm{ng} / \mathrm{mL}$ bFGF, $20 \mathrm{ng} / \mathrm{mL}$ recombinant vitronectin, $1 \mathrm{mM}$ StemRegenin (SR1), $1 \mathrm{mM}$ hydrocortisone, 30$50 \mathrm{ng} / \mathrm{mL}$ SCF, $16.7 \mathrm{ng} / \mathrm{mL}$ Flt3ligand, $10 \mathrm{ng} / \mathrm{mL}$ Wnt $3 \mathrm{~A}, 2 \mathrm{mM}$ GSK3b inhibitor VIII or AA014418, 6.7-20 ng/mL BMP4, $6.7 \mathrm{ng} / \mathrm{mL} \mathrm{IL}-3,6.7 \mathrm{ng} / \mathrm{mL} \mathrm{IL}-11$, $50 \mathrm{mM}$ IBMX, $1.3 \mathrm{U} / \mathrm{mL}$ EPO, 30 $\mathrm{ng} / \mathrm{mL}$ VEGF, $10 \mathrm{ng} / \mathrm{mL}$ FGFa, 10 $\mathrm{ng} / \mathrm{mL} \mathrm{IGF}, 10 \mathrm{ng} / \mathrm{mL}$ TPO, $5 \mathrm{mg} /$ $\mathrm{mL}$ heparin, $50 \mathrm{mM}$ IBMX, $0.4 \mathrm{ng} /$ $\mathrm{mL}$ b-estradiol

VEGF, BMP4, Flt3-ligand, IL-3, IL-6, SCF, TPO, EPO

IDMEM medium, $0.2 \mathrm{mg} / \mathrm{mL}$ insulin, $0.11 \mathrm{mg} / \mathrm{mL}$ transferrin, $0.1 \mathrm{\mu g} / \mathrm{mL}$ sodium selenite, 0.45 $\mathrm{mM}$ a-mono-thioglycerol, $50 \mathrm{\mu g} /$ $\mathrm{mL} \mathrm{AA}, 20 \mathrm{ng} / \mathrm{mL}$ VEGF, $50 \mathrm{ng} /$ $\mathrm{mL} \mathrm{SCF}, 50 \mathrm{ng} / \mathrm{ml}$ fms-related tyrosine kinase 3 ligand, $50 \mathrm{ng} /$ $\mathrm{mL}$ TPO, $5 \mu \mathrm{g} / \mathrm{mL} \mathrm{IL}-3,10 \mathrm{ng} / \mathrm{mL}$ BMP4,

$5 \mathrm{U} / \mathrm{ml}$ EPO

CD34, CD43, CD45, CD31, CD144, Matrigel, mTeSR1 medium, CD235a, CD11b, CD14, CD3, CD4, CD5, CD7, CD8a stemline II, ITS, $20 \mathrm{ng} / \mathrm{mL}$ BMP4, $5 \mathrm{ng} / \mathrm{mL}$ Activin A, $5 \mathrm{ng} / \mathrm{mL}$ bFGF, $40 \mathrm{ng} / \mathrm{mL}$ VEGF, $50 \mathrm{ng} / \mathrm{mL}$ SCF, $50 \mathrm{ng} / \mathrm{mL}$ Flt3-ligand, $10 \mathrm{ng} /$
The growth rate of erythroid cells from iPSCderived CD34+ HSCs was slightly higher

The large-scale expansion of human iPSC-derived erythroid cells under feeder-free and serumfree culture condition

Human iPSC-derived CD43-expressing hematopoietic cells are a suitable option for in vitro erythropoiesis

MSC-derived iPSCS produced more efficient definitive erythroid cells with higher b-globin expression

UM171 improved in vitro derivation of HSCs from human iPSCs 
Table 1 In vitro differentiation of human induced pluripotent stem cells (iPSCs) into red blood cells (RBCs) (Continued)

\begin{tabular}{|c|c|c|c|c|c|}
\hline $\begin{array}{l}\text { Human iPSC cell } \\
\text { source }\end{array}$ & $\begin{array}{l}\text { Reprogramming } \\
\text { transcription factors }\end{array}$ & $\begin{array}{l}\text { Cluster of differentiation (CD) } \\
\text { markers }\end{array}$ & iPSC culture condition & Results & Refs. \\
\hline & & & $\begin{array}{l}\mathrm{mL} \text { TPO, } 50 \mathrm{ng} / \mathrm{mL} \mathrm{IL}-3,50 \mathrm{ng} / \mathrm{mL} \\
\mathrm{IL}-6 \text {, }\end{array}$ & & \\
\hline $\begin{array}{l}\text { Cord blood CD34+ } \\
\text { cells and CD36+ } \\
\text { erythroblasts }\end{array}$ & $\begin{array}{l}\text { OCT4, SOX2, KLF4, } \\
\text { and c- MYC }\end{array}$ & $\begin{array}{l}\text { CD34+/CD45+ (hematopoietic } \\
\text { progenitors), CD36+/CD45+ } \\
\text { (erythroid precursors) }\end{array}$ & $\begin{array}{l}\text { Matrigel, STEMdiff'M APEL }{ }^{\mathrm{TM}} 2 \\
\text { medium, } 5 \% \text { PFHM-II Protein-free } \\
\text { Hybridoma Medium, } 5 \mathrm{ng} / \mathrm{mL} \text { IL- } \\
\text { 3, } 100 \mathrm{ng} / \mathrm{mL} \text { SCF, } 3 \mathrm{U} / \mathrm{mL} \text { EPO, } \\
10 \% \text { human plasma, } 10 \mu \mathrm{g} / \mathrm{mL} \text { in- } \\
\text { sulin, } 330 \mu \mathrm{m} / \mathrm{mL} \text { human } \\
\text { holotransferrin }\end{array}$ & $\begin{array}{l}\text { Prolonged human iPSC- } \\
\text { derived RBCs in a simpli- } \\
\text { fied cell culture system } \\
\text { with low cytokine } \\
\text { support }\end{array}$ & [31] \\
\hline WT-iPSC line & & $\begin{array}{l}\text { CD34, CD38, CD45, CD90, CD117, } \\
\text { CD133 }\end{array}$ & $\begin{array}{l}\text { Vitronectin, OP9 feeder layer, } \\
\text { MEM medium with 10\% FBS, } \\
100 \mu \mathrm{M} \text { MTG, } 50 \mu \mathrm{g} / \mathrm{mL} \text { AA }\end{array}$ & $\begin{array}{l}\text { NOX4 has a significant } \\
\text { role in the early stages of } \\
\text { hematopoietic } \\
\text { differentiation from iPSCS }\end{array}$ & [85] \\
\hline $\begin{array}{l}\text { Bone marrow } \\
\text { stromal cells from a } \\
\text { SCD patient }\end{array}$ & & $\begin{array}{l}\text { CD31, CD34, CD36, CD38, CD41a, } \\
\text { CD43, CD45, CD45RA, CD49f, } \\
\text { CD71, CD73, CD90, CD144, } \\
\text { CD184 }\end{array}$ & $\begin{array}{l}\text { mTeSR1 media, Matrigel, IMDM, } \\
\text { C3H10T1/2 feeder cells, } 1 \% \text { ITS, } \\
50 \mathrm{mg} / \mathrm{mL} \text { AA, } 0.45 \mathrm{mM} \text { a- } \\
\text { monothioglycerol, } 20 \mathrm{ng} / \mathrm{mL} \text { hu- } \\
\text { man VEGF, } 15 \% \text { FBS or } 20 \% \mathrm{KSR} \text {, } \\
\text { OP9 feeder cells, } 50 \mathrm{ng} / \mathrm{mL} \text { FL, } \\
50 \mathrm{ng} / \mathrm{mL} \text { TPO, } 5 \mathrm{ng} / \mathrm{mL} \mathrm{IL} 3,50 \\
\mathrm{ng} / \mathrm{mL} \mathrm{SCF}, 5 \mathrm{U} / \mathrm{mL} \text { EPO, and } 10 \\
\mathrm{ng} / \mathrm{mL} \text { BMP4, } 1.0 \mu \mathrm{MM} \text { estradiol, } \\
1.0 \mu \mathrm{M} \text { dexamethasone, } 2 \% \text { BSA, } \\
0.56 \mathrm{mg} / \mathrm{mL} \text { transferrin }\end{array}$ & $\begin{array}{l}\text { Serum-free iPSC sac- } \\
\text { derived erythroid } \\
\text { differentiation }\end{array}$ & [38] \\
\hline
\end{tabular}

IMR90 human fetal lung fibroblasts, PBMCs peripheral blood mononuclear cells, IDMEM Iscove's modified Dulbecco's medium, SCD sickle cell disease, FD-136 skin primary fibroblast cell line, OP9 mouse bone marrow stromal cell line, EB embryoid body, SCF stem cell factor, TPO thrombopoietin, FLT3 Fms-related tyrosine kinase 3 ligand, FL FLT3 ligand, BMP4 bone morphogenetic protein 4, VEGF vascular endothelial growth factor, IL-3 interleukin-3, EPO erythropoietin, ZbFGF zebrafish basic fibroblast growth factor, HSCs hematopoietic stem cells, IGF insulin-like growth factor, IBMX isobutyl methyl xanthine, MTG monothioglycerol, $A A$ ascorbic acid, KSR knockout serum replacement, BSA bovine serum albumin, ITS insulin, transferrin, selenium

illustrated the large-scale expansion of human iPSCderived erythroid cells under feeder-free and serum-free culture conditions [83]. They used several small molecules such as StemRegenin (SR1, a dual RasGAP and ERK1/2 inhibitor), BIO (archetypal GSK3b inhibitor), CHIR99021 (GSK3b inhibitor), IBMX (nonspecific inhibitor of cAMP and cGMP phosphodiesterases), and A-A014418 (GSK3b inhibitor VIII) to promote erythroid differentiation of human iPSCs [83]. Recently, Bernecker et al. described a simplified cell culture system with low cytokine support (SCF, EPO, and IL-3) to generate prolonged human iPSCderived RBCs [31]. Tursky et al. compared four serum and feeder-free iPSC hematopoietic differentiation protocols and investigated that two-dimensional (2D)-multistep protocol was simple and time- and cost-effective with the most efficient CD34+ progenitor cells [93].

\section{Primary technical challenges for the clinical application of iPSC-derived RBCs}

The in vitro production of human iPSC-derived RBCs can be an alternative treatment option for patients with blood disorders [94]. Many attempts have been examined to differentiate iPSCs into RBCs, but no clinical trials using iPSC-derived RBCs transfusion have been conducted [60]. Table 2 shows patient-specific iPSCs models of hematological disorders.
Before iPSC-derived RBCs derivatives can be used in the clinic, it is essential to found the risks and processrelated challenges associated with the generation of latestage maturity RBCs in vitro [132, 133]. The technology of manufacturing functional erythroid cells from iPSCs needs a sufficient number of functional RBCs in a serum free-liquid culture system or chemically defined media, which is necessary for any potential clinical trials [134, 135]. Human iPSCs may be considered as an unlimited source of RBCs than HSCs, but generating mature RBCs from iPSCs is still an inefficient process and less strict experiment protocols using low-cost media and reagents are needed [136]. Thus, the challenge for large-scale expansion of iPSC-derived erythroid cells needs to be overcome $[8,60]$.

The use of small molecules as substitutes for growth factors or various cytokines can reduce side effects and media costs $[137,138]$. Further studies are necessary to understand which genetic or epigenetic alternations improve the terminal differentiation of iPSC-derived erythroid cells [139]. Recent studies have shown that histone deacetylases such as histone deacetylase 2 (HDAC2) are the critical regulator for chromatin condensation in mouse erythroblasts [140]. Administration of HDAC2 inhibitors can suppress the terminal differentiation of human erythroid precursors [139]. It is 
Table 2 Patient-specific iPSC models of hematological disorders

\begin{tabular}{|c|c|c|c|}
\hline Authors & Disorder & iPSC cell source & Ref. \\
\hline Ye et al. 2009 & Myeloproliferative disorders (MPDs) & iPSCs from peripheral blood CD34+ cells of patients with MPDs & [95] \\
\hline Zou et al. 2011 & Chronic granulomatous disease (CGD) & iPSCs from patient with X-linked CGD & [96] \\
\hline $\begin{array}{l}\text { Kumano et al. } \\
2012\end{array}$ & Chronic myelogenous leukemia (CML) & iPSCs from imatinib-sensitive CML patient & [97] \\
\hline Chang et al. 2012 & a-Thalassemia (a-Thal) & iPSCs from a-Thal fibroblasts & [98] \\
\hline $\begin{array}{l}\text { Garçon et al. } \\
2013\end{array}$ & Diamond Blackfan anemia (DBA) & iPSCs from fibroblasts of DBA patient & [99] \\
\hline Bedel et al. 2013 & CML & iPSCs from CD34+ blood cells isolated from CML patients & [100] \\
\hline Yuan et al. 2013 & Paroxysmal nocturnal hemoglobinuria (PNH) & iPSCs from adult male dermal fibroblasts & [101] \\
\hline Saliba et al. 2013 & Polycythemia vera (PV) & $\begin{array}{l}\text { iPSCs from } 2 \text { polycythemia vera patients carrying a heterozygous and a } \\
\text { homozygous mutated JAK2 JAK2 } 2617 \mathrm{~F}\end{array}$ & [102] \\
\hline $\begin{array}{l}\text { Sakurai et al. } \\
2014\end{array}$ & Familial platelet disorder (FPD)/AML & iPSCs from three distinct FPD/AML pedigrees & [103] \\
\hline Sun et al. 2014 & Sickle cell disease (SCD) & iPSCs from patient with SCD mutation & [104] \\
\hline Ye et al. 2014 & PV & iPSCs from PV patient blood & [105] \\
\hline Xie et al. 2014 & $\beta$-Thalassemia ( $\beta$-Thal) & iPSCs from patient with $\beta$-Thal & [106] \\
\hline $\begin{array}{l}\text { Amabile et al. } \\
2015\end{array}$ & CML & $\begin{array}{l}\text { Primary bone marrow cells obtained from a BCR-ABL-positive CML } \\
\text { patient }\end{array}$ & [107] \\
\hline Ge et al. 2015 & DBA & iPSCs from DBA patients carrying RPS19 or RPL5 mutations & [108] \\
\hline Park et al. 2015 & Hemophilia A (HA) & $\begin{array}{l}\text { iPSCs from patients with chromosomal inversions that involve introns } 1 \\
\text { and } 22 \text { of the F8 gene }\end{array}$ & [109] \\
\hline Kotini et al. 2015 & Myelodysplastic syndromes (MDS) & iPSCs from hematopoietic cells of MDS patients & [110] \\
\hline $\begin{array}{l}\text { Huang et al. } \\
2015\end{array}$ & SCD & $\begin{array}{l}\text { iPSCs from adult patients of SCD, which harbor the homozygous } \beta^{5} \\
\text { mutation in the HBB gene }\end{array}$ & [111] \\
\hline Chang et al. 2015 & Severe combined immunodeficiency (SCID) & iPSCs from SCID patients with Janus family kinase (JAK3)-deficient cells & [112] \\
\hline $\begin{array}{l}\text { Menon et al. } \\
2015\end{array}$ & X-linked severe SCID (SCID-X1) & iPSCs from SCID-X1 patients & [113] \\
\hline $\begin{array}{l}\text { Ingrungruanglert } \\
\text { et al. } 2015\end{array}$ & Wiskott-Aldrich syndrome (WAS) & iPSCs from patients with mutations in WASP & [114] \\
\hline Wu et al. 2016 & $\mathrm{HA}$ & iPSCs from peripheral blood from severe HA patients & [115] \\
\hline Pang et al. 2016 & $\mathrm{HA}$ & iPSCs from patients with severe $\mathrm{HA}$ & [116] \\
\hline Niu et al. 2016 & $\beta$-Thal & iPSCs from patient with $\beta$-Thal & [117] \\
\hline $\begin{array}{l}\text { Laskowski et al. } \\
2016\end{array}$ & WAS & iPSCs from CD34+ hematopoietic progenitor cells of a WAS patient & [118] \\
\hline $\begin{array}{l}\text { Doulatov et al. } \\
2017\end{array}$ & DBA & iPSCs from skin fibroblasts from DBA patient & [119] \\
\hline He et al. 2017 & Hemophilia B (HB) & iPSCs from HB patient & [120] \\
\hline Chao et al. 2017 & Acute myeloid leukemia (AML) & iPSCs from AML patient & [121] \\
\hline Kotini et al. 2017 & AML & $\begin{array}{l}\text { iPSC from patients with low-risk MDS (refractory anemia [RA]), high-risk } \\
\text { MDS (RA with excess blasts [RAEB]) and secondary AML (SAML or MDS/ } \\
\text { AML from preexisting MDS) }\end{array}$ & [122] \\
\hline $\begin{array}{l}\text { Miyauchi et al. } \\
2018\end{array}$ & CML & iPSCs from the bone marrow of two CML-CP patients & [123] \\
\hline Olgasi et al. 2018 & $\mathrm{HA}$ & iPSCs from peripheral blood (PB) CD34+ cells of HA patient & [124] \\
\hline $\begin{array}{l}\text { Ramaswamy } \\
\text { et al. } 2018\end{array}$ & $\mathrm{HB}$ & iPSCs from HB patients & [125] \\
\hline Lyu et al. 2018 & $\mathrm{HB}$ & iPSC from peripheral blood mononuclear cells (PBMNCs) & [126] \\
\hline Cai et al. 2018 & $\beta$-Thal & iPSCs from patient with $\beta$-Thal & [127] \\
\hline $\begin{array}{l}\text { Wattanapanitch } \\
\text { et al. } 2018\end{array}$ & $\mathrm{HbE} / \beta-\mathrm{Thal}$ & iPSCs from Skin cells of $\mathrm{HbE} / \beta$-Thal patients & [128] \\
\hline
\end{tabular}


Table 2 Patient-specific iPSC models of hematological disorders (Continued)

\begin{tabular}{|c|c|c|c|}
\hline Authors & Disorder & iPSC cell source & Ref. \\
\hline $\begin{array}{l}\text { Sfougataki et al. } \\
2019\end{array}$ & $\begin{array}{l}\text { } \beta \text {-Thal, SCD, DBA, severe aplastic anemia (SAA), } \\
\text { dedicator of cytokinesis } 8 \text { (DOCK8) } \\
\text { immunodeficiency }\end{array}$ & $\begin{array}{l}\text { iPSCs from human bone marrow-derived mesenchymal stromal cells } \\
\text { (BM-MSCs) }\end{array}$ & [129] \\
\hline $\begin{array}{l}\text { Kohara et al. } \\
2019\end{array}$ & $\begin{array}{l}\text { Type IV congenital dyserythropoietic anemia } \\
\text { (CDA) }\end{array}$ & iPSCs from CDA patient carrying the KLF1 E325K mutation & [130] \\
\hline $\begin{array}{l}\text { Hoffmann et al. } \\
2020\end{array}$ & Severe congenital neutropenia (SCN) & $\begin{array}{l}\text { iPSCs from a SCN patient with a nonsense mutation in the glucose-6- } \\
\text { phosphatase catalytic subunit } 3 \text { (G6PC3) gene }\end{array}$ & [131] \\
\hline
\end{tabular}

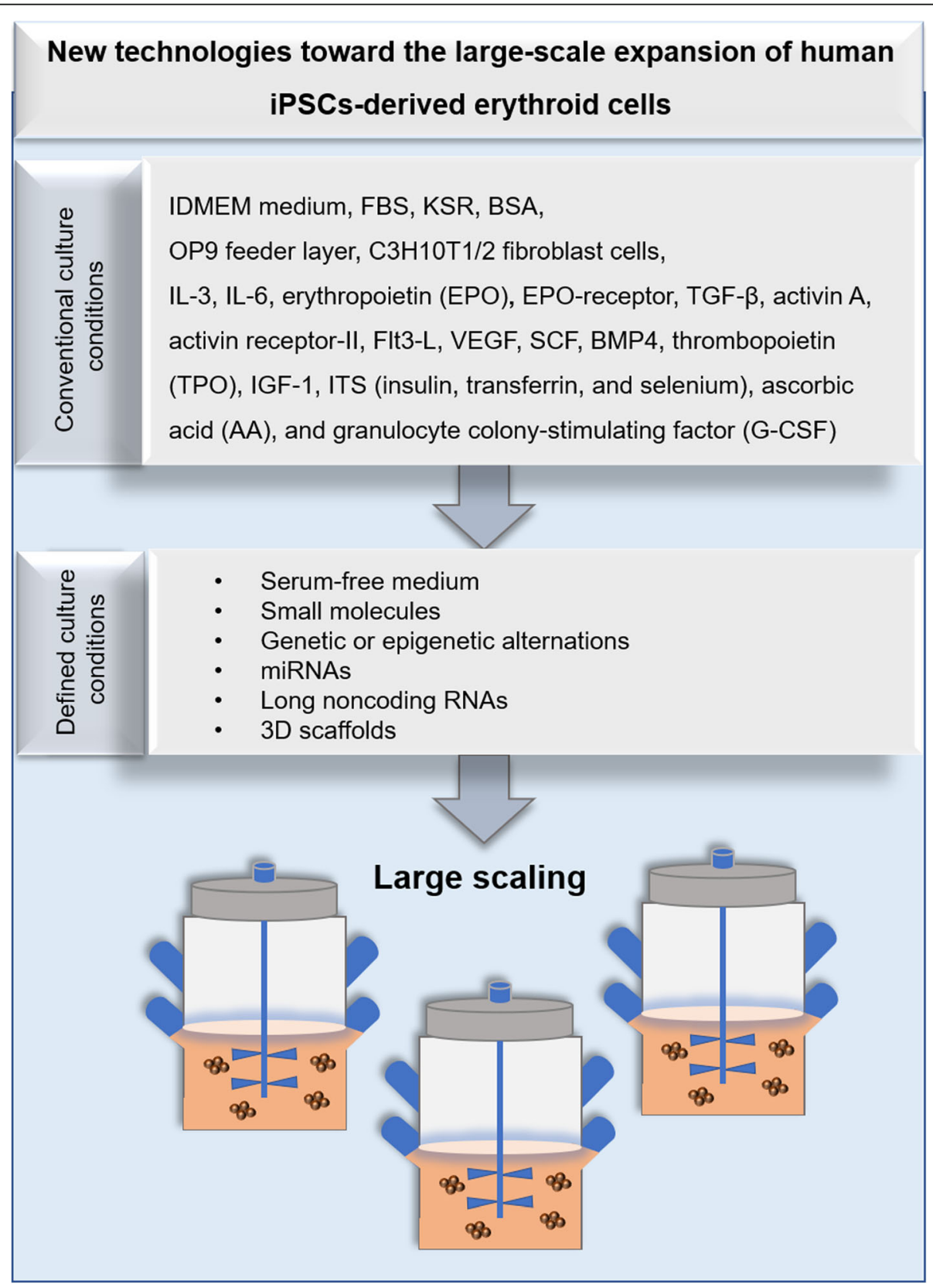

Fig. 3 New technologies toward the large-scale expansion of human iPSC-derived erythroid cells. Conventional differentiation methods compared with the novel growth factor- and serum-free culture approaches for erythroid differentiation of human iPSCS 
therefore conceivable that HDAC2 activators may enhance chromatin condensation of iPSC-derived erythroid cells [141]. MicroRNAs are important regulators that downregulate the expression of target genes [142, 143] and improve the maintenance of immature hematopoietic cells and terminal erythroid differentiation [58, 143]. Therefore, different combinations of microRNAs may increase the numbers of iPSC-derived mature RBCs [139]. In addition to microRNAs, long noncoding RNAs (lncRNAs) have recently been reported that can determine the fate of stem cells [144]. A recent study has shown that long intergenic noncoding RNA erythroid prosurvival (lincRNA-EPS) can suppress apoptosis and facilitate erythropoiesis [145-147]. In this regard, lncRNAs might allow the generation of functional and mature RBCs from iPSCs [148, 149]. Several groups have recently shown that $3 \mathrm{D}$ scaffolds such as poly (D, L-lactide-co-glycolide), polyurethane, collagen type I, and porous polyvinyl fluoride resin can mimic the bone marrow niche and improve maintenance of immature hematopoietic cells [150-154]. Although the in vitro maturation of iPSC-derived RBCs still presents several barriers, the cultured erythroid cells from iPSCs provide an important step toward fully defined and animal-free cultivation protocols that can be applied for transfusion medicine [67]. Figure 3 shows new technologies toward the large-scale expansion of human iPSC-derived erythroid cells.

\section{Conclusion}

Reprogramming of somatic cells to the pluripotent state has been suggested as an alternative source and a novel opportunity for patient-specific stem cell-based therapies, modeling of RBCs diseases, and drug testing [155]. Previous studies have shown that human iPSCs can give rise to erythroid cells, while in vitro derivation and maintenance of enucleated erythrocytes have still been challenging [86]. Also, many hurdles such as reprogramming without retroviruses, large scale and cost-effective production of iPSC-derived enucleated RBCs, and defined xenogenic-free conditions remain to be improved before human iPSC-based therapy [156, 157]. According to good manufacturing practice (GMP) guidelines, the establishment of iPSC-derived RBCs using a reproducible, defined, and simple method will ease the translation of iPSCs into the clinic $[93,158,159]$.

\section{Abbreviations}

AA: Ascorbic acid; BMP4: Bone morphogenetic protein 4; BSA: Bovine serum albumin; EB: Embryoid body; ESCs: Embryonic stem cells; EPO: Erythropoietin; FD-136: Skin primary fibroblast cell line; GVHD: Graft-versus-host diseases; FLT3: Fms-related tyrosine kinase 3 ligand; FL: FLT3 ligand; GMP: Good manufacturing practice; HDAC2: Histone deacetylase 2; HSCs: Hematopoietic stem cells; IBMX: Isobutyl methyl xanthine; IGF: Insulin-like growth factor; IDMEM: Iscove's modified Dulbecco's medium; IMR90: Human fetal lung fibroblasts; IL-3: Interleukin-3; ITS: Insulin, transferrin, selenium; iPSCs: Induced pluripotent stem cells; LncRNAs: Long noncoding RNAs; LincRNA-EPS: Long intergenic noncoding RNA erythroid prosurvival; KSR: Knockout serum replacement; MTG: Monothioglycerol; OP9: Mouse bone marrow stromal cell line; PBMCs: Peripheral blood mononuclear cells; PSCs: Human pluripotent stem cells; SCF: Stem cell factor; SCD: Sickle cell disease; RBC: Red blood cells; TPO: Thrombopoietin; UCB: Umbilical cord blood; VEGF: Vascular endothelial growth factor; ZbFGF: Zebrafish basic fibroblast growth factor

\section{Acknowledgements}

Not applicable.

\section{Authors' contributions}

Mohsen Ebrahimi and Mehdi Forouzesh have made substantial contributions to the writing of the manuscript. Setareh Raoufi has made a substantial contribution to the design of the table. Mohammad Ramazii and Farhoodeh Ghaedrahmati contributed to the revision of the manuscript and the figures. Maryam Farzaneh has made a substantial contribution to the final revision of the manuscript. All authors have approved the submitted version of the article and have agreed to be personally accountable for the author's contributions and to ensure that questions related to the accuracy or integrity of any part of the work.

\section{Funding}

Not applicable.

\section{Availability of data and materials}

The datasets used and/or analyzed during the current study are available from the corresponding author on reasonable request.

Ethics approval and consent to participate

Not applicable.

\section{Consent for publication}

Not applicable.

\section{Competing interests}

The authors declare no conflict of interest.

\section{Author details}

${ }^{1}$ Neonatal and Children's Health Research Center, Golestan University of Medical Sciences, Gorgan, Iran. ${ }^{2}$ Legal Medicine Organization of Iran, Legal Medicine Research Center, Legal Medicine organization, Tehran, Iran. ${ }^{3}$ Faculty of Medical Sciences and Technologies, Science and Research Branch, Islamic Azad University, Tehran, Iran. ${ }^{4}$ Kerman University of Medical Sciences, University of Kerman, Kerman, Iran. ${ }^{5}$ Department of Immunology, School of Medicine, Isfahan University of Medical Sciences, Isfahan, Iran. ${ }^{6}$ Physiology Research Center, Ahvaz Jundishapur University of Medical Sciences, Ahvaz, Iran.

Received: 22 September 2020 Accepted: 25 October 2020

Published online: 16 November 2020

\section{References}

1. Focosi D, Amabile G. Induced pluripotent stem cell-derived red blood cells and platelet concentrates: from bench to bedside. Cells. 2018;7:2

2. Shah S, Huang $X$, Cheng L. Concise review: stem cell-based approaches to red blood cell production for transfusion. Stem Cells Transl Med. 2014;3: 346-55.

3. Sahu S, Hemlata, Verma A, Adverse events related to blood transfusion. Indian J Anaesth 2014; 58: 543-551.

4. Mujahid A, Dickert FL. Blood group typing: from classical strategies to the application of synthetic antibodies generated by molecular imprinting. Sensors (Basel). 2015:16:51.

5. Moras M, Lefevre SD, Ostuni MA. From erythroblasts to mature red blood cells: organelle clearance in mammals. Front Physiol. 2017;8:1076.

6. Xi J, Li Y, Wang R, Wang Y, Nan X, He L, Zhang P, Chen L, Yue W, Pei X. In vitro large scale production of human mature red blood cells from hematopoietic stem cells by coculturing with human fetal liver stromal cells. Biomed Res Int. 2013;2013:1-12.

7. Giarratana M-C, Kobari L, Lapillonne H, Chalmers D, Kiger L, Cynober T, Marden MC, Wajcman H, Douay L. Ex vivo generation of fully mature 
human red blood cells from hematopoietic stem cells. Nat Biotechnol. 2005; 23:69-74.

8. Seo Y, Shin K-H, Kim HH, Kim H-S. Current advances in red blood cell generation using stem cells from diverse sources. Stem Cells Int. 2019;2019: 9281329.

9. Sun $\mathrm{S}$, Peng $\mathrm{Y}$, Liu J. Research advances in erythrocyte regeneration sources and methods in vitro. Cell Regeneration. 2018;7:45-9.

10. Christaki E-E, Politou M, Antonelou M, Athanasopoulos A, Simantirakis E, Seghatchian J, Vassilopoulos G. Ex vivo generation of transfusable red blood cells from various stem cell sources: a concise revisit of where we are now. Transfus Apher Sci. 2019;58:108-12.

11. Wilkinson AC, Igarashi KJ, Nakauchi H. Haematopoietic stem cell self-renewal in vivo and ex vivo. Nat Rev Genet. 2020;21:541-54.

12. Anstee DJ. Production of erythroid cells from human embryonic stem cells (hESC) and human induced pluripotent stem cells (hiPS). Transfus Clin Biol. 2010;17:104-9.

13. Bouhassira EE. Concise review: production of cultured red blood cells from stem cells. Stem Cells Transl Med. 2012;1:927-33.

14. Trakarnsanga K, Griffiths RE, Wilson MC, Blair A, Satchwell TJ, Meinders M, Cogan N, Kupzig S, Kurita R, Nakamura Y, Toye AM, Anstee DJ, Frayne J. An immortalized adult human erythroid line facilitates sustainable and scalable generation of functional red cells. Nat Commun. 2017;8:14750.

15. Wang G, Farzaneh M. Mini review; differentiation of human pluripotent stem cells into oocytes. Curr Stem Cell Res Ther. 2020;15:301-7.

16. Zhao N, Sheng M, Wang X, Li Y, Farzaneh M, Differentiation of human induced pluripotent stem cells into male germ cells. Current Stem Cell Res Therapy 2020.

17. Kolagar TA, Farzaneh M, Nikkar N, Khoshnam SE. Human pluripotent stem cells in neurodegenerative diseases: potentials, advances and limitations. Current Stem Cell Res Therapy. 2020;15:102-10.

18. Lu S-J, Feng Q, Park J S, Vida L, Lee B-S, Strausbauch M, Wettstein P J, Honig $G R$, Lanza R, Biologic properties and enucleation of red blood cells from human embryonic stem cells. Blood J Am Soc Hematol 2008; 112: 44754484 .

19. Elcheva I, Brok-Volchanskaya V, Kumar A, Liu P, Lee J-H, Tong L, Vodyanik M, Swanson S, Stewart R, Kyba M. Direct induction of haematoendothelial programs in human pluripotent stem cells by transcriptional regulators. Nat Commun. 2014:5:1-11.

20. Acosta ND, Golub SH. The new federalism: state policies regarding embryonic stem cell research. J Law Med Ethics. 2016;44:419-36.

21. Ma F, Ebihara Y, Umeda K, Sakai H, Hanada S, Zhang H, Zaike Y, Tsuchida E, Nakahata T, Nakauchi H, Tsuji K. Generation of functional erythrocytes from human embryonic stem cell-derived definitive hematopoiesis. Proc Natl Acad Sci. 2008;105:13087-92.

22. Esposito MT. Blood factory: which stem cells? BMC Hematology. 2018;18:10.

23. Zeuner A, Martelli F, Vaglio S, Federici G, Whitsett C, Migliaccio AR. Concise review: stem cell-derived erythrocytes as upcoming players in blood transfusion. Stem Cells. 2012;30:1587-96.

24. Moradi S, Mahdizadeh H, Šarić T, Kim J, Harati J, Shahsavarani H, Greber B, Moore JB. Research and therapy with induced pluripotent stem cells (iPSCs): social, legal, and ethical considerations. Stem Cell Res Ther. 2019;10:1-13.

25. Pereira Daoud A M, Popovic M, Dondorp W J, Trani Bustos M, Bredenoord A L, Chuva De Sousa Lopes S M, Van Den Brink S C, Roelen B A, De Wert G M, Heindryckx B, Modelling human embryogenesis: embryo-like structures spark ethical and policy debate. Hum Reprod Update 2020.

26. Fibach E. Erythropoiesis in vitro-a research and therapeutic tool in thalassemia. J Clin Med. 2019;8:2124.

27. Luo J, Qin L, Zhao L, Gui L, Ellis MW, Huang Y, Kural MH, Clark JA, Ono S, Wang J. Tissue-engineered vascular grafts with advanced mechanical strength from human iPSCs. Cell Stem Cell. 2020;26:251-61 e258.

28. Shi J, Farzaneh M, Khoshnam SE. Yes-associated protein and PDZ binding motif: a critical signaling pathway in the control of human pluripotent stem cells self-renewal and differentiation. Cellular Reprogramming. 2020;22:55-61.

29. Farzaneh M, Derakhshan Z, Hallajzadeh J, Sarani NH, Nejabatdoust A, Khoshnam SE. Suppression of TGF- $\beta$ and ERK signaling pathways as a new strategy to provide rodent and non-rodent pluripotent stem cells. Current Stem Cell Res Therapy. 2019;14:466-73.

30. Zhao Y, Liu H, Zhao C, Dang P, Li H, Farzaneh M. Paracrine interactions involved in human induced pluripotent stem cells differentiation into chondrocytes. Current Stem Cell Res Therapy. 2020;15:233-42.
31. Bernecker C, Ackermann M, Lachmann N, Rohrhofer L, Zaehres H, AraúzoBravo MJ, van den Akker E, Schlenke P, Dorn I. Enhanced ex vivo generation of erythroid cells from human induced pluripotent stem cells in a simplified cell culture system with low cytokine support. Stem Cells Dev. 2019;28: 1540-51.

32. Daniel MG, Sachs D, Bernitz JM, Fstkchyan Y, Rapp K, Satija N, Law K, Patel F, Gomes AM, Kim H-S. Induction of human hemogenesis in adult fibroblasts by defined factors and hematopoietic coculture. FEBS Lett. 2019.

33. Lapillonne H, Kobari L, Mazurier C, Tropel P, Giarratana M-C, Zanella-Cleon I, Kiger L, Wattenhofer-Donze M, Puccio H, Hebert N. Red blood cell generation from human induced pluripotent stem cells: perspectives for transfusion medicine. Haematologica. 2010;95:1651-9.

34. Dorn I, Klich K, Arauzo-Bravo M J, Radstaak M, Santourlidis S, Ghanjati F, Radke TF, Psathaki O E, Hargus G, Kramer J, Erythroid differentiation of human induced pluripotent stem cells is independent of donor cell type of origin. Haematologica 2015; 100: 32-41.

35. Hockemeyer $\mathrm{D}$, Jaenisch R. Induced pluripotent stem cells meet genome editing. Cell Stem Cell. 2016;18:573-86.

36. Czerwińska P, Mazurek S, Kołodziejczak I, Wiznerowicz M. Gene delivery methods and genome editing of human pluripotent stem cells. Reports Practical Oncol Radiotherapy. 2019;24:180-7.

37. Li H, Yang Y, Hong W, Huang M, Wu M, Zhao X. Applications of genome editing technology in the targeted therapy of human diseases: mechanisms, advances and prospects. Signal Transduction Targeted Therapy. 2020;5:1-23.

38. Haro-Mora JJ, Uchida N, Demirci S, Wang Q, Zou J, Tisdale JF. Biallelic correction of sickle cell disease-derived induced pluripotent stem cells (iPSCs) confirmed at the protein level through serum-free iPS-sac/erythroid differentiation. Stem Cells Transl Med. 2020;9:590-602.

39. Zivot A, Lipton JM, Narla A, Blanc L. Erythropoiesis: insights into pathophysiology and treatments in 2017. Mol Med. 2018;24:11.

40. Tsiftsoglou AS, Vizirianakis IS, Strouboulis J. Erythropoiesis: model systems, molecular regulators, and developmental programs. IUBMB Life. 2009;61: 800-30

41. Bataller A, Montalban-Bravo G, Soltysiak KA, Garcia-Manero G. The role of TGF $\beta$ in hematopoiesis and myeloid disorders. Leukemia. 2019;33:1076-89.

42. Dzierzak E, Philipsen S. Erythropoiesis: development and differentiation. Cold Spring Harbor perspectives in medicine. 2013;3:a011601.

43. Hattangadi SM, Wong P, Zhang L, Flygare J, Lodish HF. From stem cell to red cell: regulation of erythropoiesis at multiple levels by multiple proteins, RNAs, and chromatin modifications. Blood J Am Soc Hematol. 2011;118: 6258-68.

44. Huang $L J-A$, Bieker $J J$ J, A master erythroid regulator gets its own GPS. Blood J Am Society Hematol 2020; 135: 2209-2210.

45. Chen Y, Zhang J, Gu S, Yin D, An Q, An N, Weng L, Yi J, Xu J, Yin W. Mesenchymal stromal cells can be applied to red blood cells storage as a kind of cellular additive. Biosci Rep. 2017;37:1-9.

46. Bailey A, Mendicino M, Au P. An FDA perspective on preclinical development of cell-based regenerative medicine products. Nat Biotechnol. 2014;32:721.

47. Vo LT, Daley GQ. De novo generation of HSCs from somatic and pluripotent stem cell sources. Blood. 2015;125:2641-8.

48. Uchida N, Haro-Mora JJ, Fujita A, Lee DY, Winkler T, Hsieh MM, Tisdale JF. Efficient generation of $\beta$-globin-expressing erythroid cells using stromal cellderived induced pluripotent stem cells from patients with sickle cell disease. Stem Cells. 2017:35:586-96.

49. Olsen AL, Stachura DL, Weiss MJ. Designer blood: creating hematopoietic lineages from embryonic stem cells. Blood. 2006;107:1265-75.

50. Wang M, Wang H, Wen Y, Chen X, Liu X, Gao J, Su P, Xu Y, Zhou W, Shi L. MEIS2 regulates endothelial to hematopoietic transition of human embryonic stem cells by targeting TAL1. Stem Cell Res Ther. 2018;9:340.

51. Li P, Wu M, Lin Q, Wang $S$, Chen T, Jiang H. Key genes and integrated modules in hematopoietic differentiation of human embryonic stem cells: a comprehensive bioinformatic analysis. Stem Cell Res Ther. 2018;9:1-10.

52. Iriguchi S, Kaneko S, In vitro differentiation of T Cells: from human embryonic stem cells and induced pluripotent stem cells, in: In vitro differentiation of T-cells, Springer, 2019, pp. 59-70.

53. Kaufman DS, Hanson ET, Lewis RL, Auerbach R, Thomson JA. Hematopoietic colony-forming cells derived from human embryonic stem cells. Proc Natl Acad Sci. 2001;98:10716-21.

54. Qiu C, Hanson E, Olivier E, Inada M, Kaufman DS, Gupta S, Bouhassira EE. Differentiation of human embryonic stem cells into hematopoietic cells by 
coculture with human fetal liver cells recapitulates the globin switch that occurs early in development. Exp Hematol. 2005;33:1450-8.

55. Ohnuki M, Takahashi K. Present and future challenges of induced pluripotent stem cells. Philosophical Transactions of the Royal Society B: Biological Sciences. 2015;370:20140367.

56. Hanna J, Wernig M, Markoulaki S, Sun C-W, Meissner A, Cassady JP, Beard C, Brambrink T, Wu L-C, Townes TM. Treatment of sickle cell anemia mouse model with iPS cells generated from autologous skin. Science. 2007;318:1920-3.

57. Schenke-Layland K, Rhodes KE, Angelis E, Butylkova Y, Heydarkhan-Hagvall S, Gekas C, Zhang R, Goldhaber Jl, Mikkola HK, Plath K. Reprogrammed mouse fibroblasts differentiate into cells of the cardiovascular and hematopoietic lineages. Stem Cells. 2008:26:1537-46.

58. Ferreira AF, Calin GA, Picanço-Castro V, Kashima S, Covas DT, de Castro FA. Hematopoietic stem cells from induced pluripotent stem cells-considering the role of microRNA as a cell differentiation regulator. J Cell Sci. 2018:131:1-8.

59. Ruiz JP, Chen G, Mora JJH, Keyvanfar K, Liu C, Zou J, Beers J, Bloomer H, Qanash H, Uchida N. Robust generation of erythroid and multilineage hematopoietic progenitors from human iPSCs using a scalable monolayer culture system. Stem Cell Res. 2019;41:101600,

60. Haake K, Ackermann M, Lachmann N. Concise review: towards the clinical translation of induced pluripotent stem cell-derived blood cells—ready for take-off. Stem Cells Transl Med. 2019;8:332-9.

61. Takahashi K, Yamanaka S. Induction of pluripotent stem cells from mouse embryonic and adult fibroblast cultures by defined factors. Cell. 2006;126:663-76.

62. Yu J, Vodyanik MA, Smuga-Otto K, Antosiewicz-Bourget J, Frane JL, Tian S, Nie J, Jonsdottir GA, Ruotti V, Stewart R. Induced pluripotent stem cell lines derived from human somatic cells. Science. 2007;318:1917-20.

63. Allsopp TE, Ebneth A, Cabrera-Socorro A. Deploying human pluripotent stem cells to treat central nervous system disorders: facts, challenges and realising the potential. Stem Cell Res. 2019;41:101581.

64. Volpato V, Smith J, Sandor C, Ried JS, Baud A, Handel A, Newey SE, Wessely F, Attar M, Whiteley E. Reproducibility of molecular phenotypes after longterm differentiation to human iPSC-derived neurons: a multi-site omics study. Stem cell reports. 2018;11:897-911.

65. Klein D. iPSCs-based generation of vascular cells: reprogramming approaches and applications. Cell Mol Life Sci. 2018;75:1411-33.

66. Horton PD, Sandeep D, Wenzel PL. Mechanoregulation in hematopoiesis and hematologic disorders. Current Stem Cell Reports. 2020;6:86-95.

67. Wattanapanitch M. Recent updates on induced pluripotent stem cells in hematological disorders. Stem Cells Int. 2019:2019:5171032.

68. Shono Y, Shiratori S, Kosugi-Kanaya M, Ueha S, Sugita J, Shigematsu A, Kondo T, Hashimoto D, Fujimoto K, Endo T, Nishio M, Hashino S, Matsuno Y, Matsushima K, Tanaka J, Imamura M, Teshima T. Bone marrow graft-versushost disease: evaluation of its clinical impact on disrupted hematopoiesis after allogeneic hematopoietic stem cell transplantation. Biology of Blood and Marrow Transplantation. 2014;20:495-500.

69. Pagliuca S, Prata PH, Xhaard A, Frieri C, Giannoni L, Del Galy AS, Brignier A, de Fontbrune FS, Michonneau D, Dhedin N. Long-term outcomes and risk factor analysis of steroid-refractory graft versus host disease after hematopoietic stem cell transplantation. Bone Marrow Transplant. 2020;12:1-12.

70. Staal FJT, Aiuti A, Cavazzana M. Autologous stem-cell-based gene therapy for inherited disorders: state of the art and perspectives. Front Pediatr. 2019;7:443.

71. Morgan RA, Gray D, Lomova A, Kohn DB. Hematopoietic stem cell gene therapy: progress and lessons learned. Cell Stem Cell. 2017;21:574-90.

72. Watts KL, Adair J, Kiem H-P. Hematopoietic stem cell expansion and gene therapy. Cytotherapy. 2011;13:1164-71.

73. Tajer P, Pike-Overzet K, Arias S, Havenga M, Staal FJT. Ex vivo expansion of hematopoietic stem cells for therapeutic purposes: lessons from development and the niche. Cells. 2019;8:169.

74. Kumar S, Geiger H. HSC niche biology and HSC expansion ex vivo. Trends Mol Med. 2017;23:799-819.

75. Zhou H, Rao MS. Can cord blood banks transform into induced pluripotent stem cell banks? Cytotherapy. 2015;17:756-64.

76. Winkler T, Hong SG, Decker JE, Morgan MJ, Wu C, Hughes WM, Yang Y, Wangsa D, Padilla-Nash HM, Ried T. Defective telomere elongation and hematopoiesis from telomerase-mutant aplastic anemia iPSCs. J Clin Invest. 2013:123:1952-63.

77. Hansen $M$, von Lindern $M$, van den Akker $E$, Varga E. Human-induced pluripotent stem cell-derived blood products: state of the art and future directions. FEBS Lett. 2019;593:3288-303.
78. Lachmann N, Ackermann M, Frenzel E, Liebhaber S, Brennig S, Happle C, Hoffmann D, Klimenkova O, Lüttge D, Buchegger T. Large-scale hematopoietic differentiation of human induced pluripotent stem cells provides granulocytes or macrophages for cell replacement therapies. Stem Cell Reports. 2015;4:282-96.

79. Kessel KU, Bluemke A, Schöler HR, Zaehres H, Schlenke P, Dorn I. Emergence of CD43-expressing hematopoietic progenitors from human induced pluripotent stem cells. Transfus Med Hemother. 2017;44:143-50.

80. Rowe RG, Mandelbaum J, Zon LI, Daley GQ. Engineering hematopoietic stem cells: lessons from development. Cell Stem Cell. 2016;18:707-20.

81. Choi KD, Yu J, Smuga-Otto K, Salvagiotto G, Rehrauer W, Vodyanik M, Thomson J, Slukvin I. Hematopoietic and endothelial differentiation of human induced pluripotent stem cells. Stem Cells. 2009;27:559-67.

82. Dias J, Gumenyuk M, Kang H, Vodyanik M, Yu J, Thomson JA, Slukvin II. Generation of red blood cells from human induced pluripotent stem cells. Stem Cells Dev. 2011;20:1639-47.

83. Olivier EN, Marenah L, McCahill A, Condie A, Cowan S, Mountford JC. Highefficiency serum-free feeder-free erythroid differentiation of human pluripotent stem cells using small molecules. Stem Cells Transl Med. 2016;5:1394-405.

84. Li X, Xia C, Wang T, Liu L, Zhao Q, Yang D, Hu F, Zhang M, Huang K, Geng Y, Zheng Y, Guan Y, Wu H, Chen X, Pan G, Chen J, Du J, Wang J. Pyrimidoindole derivative UM171 enhances derivation of hematopoietic progenitor cells from human pluripotent stem cells. Stem Cell Res. 2017;21:32-9.

85. Brault J, Vigne B, Meunier M, Beaumel S, Mollin M, Park S, Stasia MJ. NOX4 is the main NADPH oxidase involved in the early stages of hematopoietic differentiation from human induced pluripotent stem cells. Free Radic Biol Med. 2020;146:107-18.

86. Shen J, Zhu Y, Lyu C, Feng Z, Lyu S, Zhao Y, Hoyle DL, Ji G, Miao W, Zhang $X$, Cheng L, Brodsky RA, Cheng T, Wang ZZ. Sequential cellular niches control the generation of enucleated erythrocytes from human pluripotent stem cells. Haematologica. 2020;105:e48-51.

87. Ishigaki T, Sudo K, Hiroyama T, Miharada K, Ninomiya H, Chiba S, Nagasawa T, Nakamura Y. Human hematopoietic stem cells can survive in vitro for several months. Adv Hematol. 2009;2009:936761.

88. Kim K, Doi A, Wen B, Ng K, Zhao R, Cahan P, Kim J, Aryee M, Ji H, Ehrlich L. Epigenetic memory in induced pluripotent stem cells. Nature. 2010;467:285-90.

89. Noguchi H, Miyagi-Shiohira C, Nakashima Y. Induced tissue-specific stem cells and epigenetic memory in induced pluripotent stem cells. Int J Mol Sci. 2018;19:930.

90. Sillar JR, Germon ZP, Deluliis GN, Dun MD. The role of reactive oxygen species in acute myeloid leukaemia. Int J Mol Sci. 2019;20:6003.

91. Prieto-Bermejo R, Romo-González M, Pérez-Fernández A, ljurko C, HernándezHernández Á. Reactive oxygen species in haematopoiesis: leukaemic cells take a walk on the wild side. J Exp Clin Cancer Res. 2018;37:125.

92. Maria Florencia T, Donaires FS, Silva TC, Moreira LF, Armenteros Y, Calado RT. UM171 regulates the hematopoietic differentiation of human acquired aplastic anemia-derived induced pluripotent stem cells. Blood. 2019;134:2500.

93. Tursky ML, Loi TH, Artuz CM, Alateeq S, Wolvetang EJ, Tao H, Ma DD, Molloy TJ. Direct comparison of four hematopoietic differentiation methods from human induced pluripotent stem cells. Stem Cell Reports. 2020;15:735-48,

94. Cheng T. Hematopoietic differentiation of human pluripotent stem cells: Springer; 2015.

95. Ye Z, Zhan H, Mali P, Dowey S, Williams DM, Jang Y-Y, Dang CV, Spivak JL, Moliterno AR, Cheng L. Human-induced pluripotent stem cells from blood cells of healthy donors and patients with acquired blood disorders. Blood J Am Soc Hematol. 2009;1 14:5473-80.

96. Zou J, Sweeney CL, Chou B-K, Choi U, Pan J, Wang H, Dowey SN, Cheng L, Malech HL. Oxidase-deficient neutrophils from X-linked chronic granulomatous disease iPS cells: functional correction by zinc finger nuclease-mediated safe harbor targeting. Blood J Am Soc Hematol. 2011;117:5561-72.

97. Kumano K, Arai S, Hosoi M, Taoka K, Takayama N, Otsu M, Nagae G, Ueda K, Nakazaki K, Kamikubo Y. Generation of induced pluripotent stem cells from primary chronic myelogenous leukemia patient samples. Blood J Am Soc Hematol. 2012;1 19:6234-42.

98. Chang C-J, Bouhassira E E, Zinc-finger nuclease-mediated correction of athalassemia in iPS cells. Blood J Am Society Hematol 2012; 120: 3906-3914.

99. Garçon L, Ge J, Manjunath SH, Mills JA, Apicella M, Parikh S, Sullivan LM, Podsakoff GM, Gadue P, French DL, Mason PJ, Bessler M, Weiss MJ. Ribosomal and hematopoietic defects in induced pluripotent stem cells derived from Diamond Blackfan anemia patients. Blood. 2013;122:912-21. 
100. Bedel A, Pasquet J-M, Lippert E, Taillepierre M, Lagarde V, Dabernat S, Dubus P, Charaf L, Beliveau F, de Verneuil H. Variable behavior of iPSCS derived from CML patients for response to TKI and hematopoietic differentiation. PLoS One. 2013;8:e71596.

101. Yuan X, Braunstein EM, Ye Z, Liu CF, Chen G, Zou J, Cheng L, Brodsky RA. Generation of glycosylphosphatidylinositol anchor protein-deficient blood cells from human induced pluripotent stem cells. Stem Cells Transl Med. 2013;2:819-29.

102. Saliba J, Hamidi S, Lenglet G, Langlois T, Yin J, Cabagnols X, Secardin L, Legrand C, Galy A, Opolon P. Heterozygous and homozygous JAK2 V617F states modeled by induced pluripotent stem cells from myeloproliferative neoplasm patients. PLoS One. 2013;8:e74257.

103. Sakurai M, Kunimoto H, Watanabe N, Fukuchi Y, Yuasa S, Yamazaki S, Nishimura T, Sadahira K, Fukuda K, Okano H. Impaired hematopoietic differentiation of RUNX1-mutated induced pluripotent stem cells derived from FPD/AML patients. Leukemia. 2014;28:2344-54.

104. Sun $\mathrm{N}$, Zhao $\mathrm{H}$. Seamless correction of the sickle cell disease mutation of the HBB gene in human induced pluripotent stem cells using TALENs. Biotechnol Bioeng. 2014;111:1048-53.

105. Ye Z, Liu CF, Lanikova L, Dowey SN, He C, Huang X, Brodsky RA, Spivak JL, Prchal JT, Cheng L. Differential sensitivity to JAK inhibitory drugs by isogenic human erythroblasts and hematopoietic progenitors generated from patient-specific induced pluripotent stem cells. Stem Cells. 2014;32:269-78.

106. Xie F, Ye L, Chang JC, Beyer Al, Wang J, Muench MO, Kan YW. Seamless gene correction of $\beta$-thalassemia mutations in patient-specific iPSCs using CRISPR/Cas9 and piggyBac. Genome Res. 2014;24:1526-33.

107. Amabile G, Di Ruscio A, Müller F, Welner RS, Yang H, Ebralidze AK, Zhang $H$, Levantini E, Qi L, Martinelli G. Dissecting the role of aberrant DNA methylation in human leukaemia. Nat Commun. 2015;6:1-10.

108. Ge J, Apicella M, Mills JA, Garçon L, French DL, Weiss MJ, Bessler M, Mason $P J$. Dysregulation of the transforming growth factor $\beta$ pathway in induced pluripotent stem cells generated from patients with Diamond Blackfan anemia. PLoS One. 2015;10:e0134878.

109. Park C-Y, Kim DH, Son JS, Sung JJ, Lee J, Bae S, Kim J-H, Kim D-W, Kim J-S. Functional correction of large factor VIII gene chromosomal inversions in hemophilia A patient-derived iPSCs using CRISPR-Cas9. Cell Stem Cell. 2015; 17:213-20.

110. Kotini AG, Chang C-J, Boussaad I, Delrow JJ, Dolezal EK, Nagulapally AB, Perna F, Fishbein GA, Klimek VM, Hawkins RD. Functional analysis of a chromosomal deletion associated with myelodysplastic syndromes using isogenic human induced pluripotent stem cells. Nat Biotechnol. 2015;33:646-55

111. Huang X, Wang Y, Yan W, Smith C, Ye Z, Wang J, Gao Y, Mendelsohn L, Cheng $L$. Production of gene-corrected adult beta globin protein in human erythrocytes differentiated from patient i PSC $s$ after genome editing of the sickle point mutation. Stem Cells. 2015;33:1470-9.

112. Chang C-W, Lai Y-S, Westin E, Khodadadi-Jamayran A, Pawlik KM, Lamb LS Jr, Goldman FD, Townes TM. Modeling human severe combined immunodeficiency and correction by CRISPR/Cas9-enhanced gene targeting. Cell Rep. 2015;12:1668-77.

113. Menon T, Firth AL, Scripture-Adams DD, Galic Z, Qualls SJ, Gilmore WB, Ke E, Singer $\mathrm{O}$, Anderson LS, Bornzin AR. Lymphoid regeneration from genecorrected SCID-X1 subject-derived iPSCs. Cell Stem Cell. 2015;16:367-72.

114. Ingrungruanglert $P$, Amarinthnukrowh $P$, Rungsiwiwut $R$, Maneesri-le Grand $S$, Sosothikul D, Suphapeetiporn K, Israsena N, Shotelersuk V. Wiskott-Aldrich syndrome iPS cells produce megakaryocytes with defects in cytoskeletal rearrangement and proplatelet formation. Thromb Haemost. 2015;113:792-805.

115. Wu Y, Hu Z, Li Z, Pang J, Feng M, Hu X, Wang X, Lin-Peng S, Liu B, Chen F. In situ genetic correction of F8 intron 22 inversion in hemophilia A patientspecific iPSCs. Sci Rep. 2016:6:18865.

116. Pang J, Wu Y, Li Z, Hu Z, Wang X, Hu X, Wang X, Liu X, Zhou M, Liu B. Targeting of the human $F 8$ at the multicopy rDNA locus in hemophilia $A$ patient-derived iPSCs using TALENickases. Biochem Biophys Res Commun. 2016;472:144-9.

117. Niu X, He W, Song B, Ou Z, Fan D, Chen Y, Fan Y, Sun X. Combining single strand oligodeoxynucleotides and CRISPR/Cas9 to correct gene mutations in $\beta$-thalassemia-induced pluripotent stem cells. J Biol Chem. 2016;291: 16576-85.

118. Laskowski TJ, Van Caeneghem Y, Pourebrahim R, Ma C, Ni Z, Garate Z, Crane AM, Li XS, Liao W, Gonzalez-Garay M. Gene correction of iPSCs from a Wiskott-Aldrich syndrome patient normalizes the lymphoid developmental and functional defects. Stem Cell Reports. 2016;7:139-48.
119. Doulatov S, Vo LT, Macari ER, Wahlster L, Kinney MA, Taylor AM, Barragan J, Gupta M, McGrath K, Lee H-Y. Drug discovery for Diamond-Blackfan anemia using reprogrammed hematopoietic progenitors. Sci Transl Med. 2017;9:376.

120. He Q, Wang H, Cheng T, Yuan W, Ma Y, Jiang Y, Ren Z. Genetic correction and hepatic differentiation of hemophilia B-specific human induced pluripotent stem cells. Chin Med Sci J. 2017;32:135-44.

121. Chao M P, Gentles A J, Chatterjee S, Lan F, Reinisch A, Corces M R, Xavy S, Shen J, Haag D, Chanda S, Human AML-iPSCs reacquire leukemic properties after differentiation and model clonal variation of disease. Cell Stem Cell 2017; 20: 329-344. e327.

122. Kotini A G, Chang C-J, Chow A, Yuan H, Ho T-C, Wang T, Vora S, Solovyov A, Husser C, Olszewska M, Stage-specific human induced pluripotent stem cells map the progression of myeloid transformation to transplantable leukemia. Cell stem cell 2017; 20: 315-328. e317

123. Miyauchi M, Koya J, Arai S, Yamazaki S, Honda A, Kataoka K, Yoshimi A, Taoka K, Kumano K, Kurokawa M. ADAM8 is an antigen of tyrosine kinase inhibitor-resistant chronic myeloid leukemia cells identified by patientderived induced pluripotent stem cells. Stem cell reports. 2018;10:1115-30.

124. Olgasi C, Talmon M, Merlin S, Cucci A, Richaud-Patin Y, Ranaldo G, Colangelo D, Di Scipio F, Berta GN, Borsotti C. Patient-specific iPSC-derived endothelial cells provide long-term phenotypic correction of hemophilia A. Stem cell reports. 2018;11:1391-406.

125. Ramaswamy S, Tonnu N, Menon T, Lewis BM, Green KT, Wampler D, Monahan PE, Verma IM. Autologous and heterologous cell therapy for hemophilia B toward functional restoration of factor IX. Cell Rep. 2018;23:1565-80.

126. Lyu C, Shen J, Wang R, Gu H, Zhang J, Xue F, Liu X, Liu W, Fu R, Zhang L, Li $H$, Zhang $X$, Cheng T, Yang R, Zhang L. Targeted genome engineering in human induced pluripotent stem cells from patients with hemophilia $B$ using the CRISPR-Cas9 system. Stem Cell Res Ther. 2018;9:92.

127. Cai L, Bai H, Mahairaki V, Gao Y, He C, Wen Y, Jin YC, Wang Y, Pan RL, Qasba A. A universal approach to correct various HBB gene mutations in human stem cells for gene therapy of beta-thalassemia and sickle cell disease. Stem Cells Transl Med. 2018;7:87-97.

128. Wattanapanitch $M$, Damkham N, Potirat $P$, Trakarnsanga $K$, Janan M Yaowalak U, Kheolamai P, Klincumhom N, Issaragrisil S. One-step genetic correction of hemoglobin E/beta-thalassemia patient-derived iPSCs by the CRISPR/Cas9 system. Stem Cell Res Ther. 2018;9:1-11.

129. Sfougataki I, Grafakos I, Varela I, Mitrakos A, Karagiannidou A, Tzannoudaki M, Poulou M, Mertzanian A, Roubelakis GM, Stefanaki K, Traeger-Synodinos J, Kanavakis E, Kitra V, Tzetis M, Goussetis E. Reprogramming of bone marrow derived mesenchymal stromal cells to human induced pluripotent stem cells from pediatric patients with hematological diseases using a commercial mRNA kit. Blood Cell Mol Dis. 2019;76:32-9.

130. Kohara H, Utsugisawa T, Sakamoto C, Hirose L, Ogawa Y, Ogura H, Sugawara A, Liao J, Aoki T, Iwasaki T, Asai T, Doisaki S, Okuno Y, Muramatsu H, Abe T, Kurita R, Miyamoto S, Sakuma T, Shiba M, Yamamoto T, Ohga S, Yoshida K, Ogawa S, Ito E, Kojima S, Kanno H, Tani K. KLF1 mutation E325K induces cell cycle arrest in erythroid cells differentiated from congenital dyserythropoietic anemia patient-specific induced pluripotent stem cells. Exp Hematol. 2019;73:25-37 e28.

131. Hoffmann D, Kuehle J, Lenz D, Philipp F, Zychlinski D, Lachmann N, Moritz T, Steinemann D, Morgan M, Skokowa J. Lentiviral gene therapy and vitamin B3 treatment enable granulocytic differentiation of G6PC3-deficient induced pluripotent stem cells. Gene Ther. 2020:27(6):297-306.

132. Larochelle A. Generation of red blood cells in vitro: monitoring the process for improved efficiency. Cytotherapy. 2013;15:1043-5.

133. Zhou $P$, Ouchari $M$, Xue $Y$, Yin Q. In vitro generation of red blood cells from stem cell and targeted therapy. Cell Transplant. 2020;29: 0963689720946658.

134. Kim SH, Lee EM, Han SY, Choi HS, Ryu KY, Baek EJ. Improvement of red blood cell maturation in vitro by serum-free medium optimization. Tissue Engineering Part C: Methods. 2019;25:232-42.

135. Singh V K, Saini A, Tsuji K, Sharma P B, Chandra R, Manufacturing blood ex vivo: a futuristic approach to deal with the supply and safety concerns, in: Front Cell Dev Biol, 2014. 26.

136. Park YJ, Jeon S-H, Kim H-K, Suh EJ, Choi SJ, Kim S, Kim HO. Human induced pluripotent stem cell line banking for the production of rare blood type erythrocytes. J Transl Med. 2020;18:236.

137. Feng YL, Chen DQ, Vaziri ND, Guo Y, Zhao YY. Small molecule inhibitors of epithelial-mesenchymal transition for the treatment of cancer and fibrosis. Med Res Rev. 2020;40:54-78. 
138. Farzaneh M, Zare M, Hassani SN, Baharvand H. Effects of various culture conditions on pluripotent stem cell derivation from chick embryos. J Cell Biochem. 2018;119:6325-36.

139. Li X, Wu Z, Fu X, Han W. How far are stem-cell-derived erythrocytes from the clinical arena? BioScience. 2013;63:632-43.

140. Mei Y, Liu Y, Ji P. Understanding terminal erythropoiesis: an update on chromatin condensation, enucleation, and reticulocyte maturation. Blood Rev. 2020;100740:1-10.

141. Wang P, Wang Z, Liu J. Role of HDACs in normal and malignant hematopoiesis. Mol Cancer. 2020;19:5.

142. Farzaneh M, Alishahi M, Derakhshan Z, Sarani NH, Attari F, Khoshnam SE. The expression and functional roles of miRNAs in embryonic and lineagespecific stem cells. Current Stem Cell Res Therapy. 2019;14:278-89.

143. Bissels U, Bosio A, Wagner W. MicroRNAs are shaping the hematopoietic landscape. Haematologica. 2012;97:160-7.

144. Chen J, Wang Y, Wang C, Hu J-F, Li W. LncRNA functions as a new emerging epigenetic factor in determining the fate of stem cells. Front Genet. 2020;11:277.

145. Paralkar VR, Weiss MJ. A new 'Linc' between noncoding RNAs and blood development. Genes Dev. 2011;25:2555-8.

146. Hu W, Yuan B, Flygare J, Lodish HF. Long noncoding RNA-mediated antiapoptotic activity in murine erythroid terminal differentiation. Genes Dev. 2011;25:2573-8

147. Adlakha M. Hematopoietic development from adult human embryonic stem cells and induced pluripotent stem cells; 2012.

148. Wahlster L, Daley GQ. Progress towards generation of human haematopoietic stem cells. Nat Cell Biol. 2016;18:1111-7.

149. Dalby AL. Forward programming of human pluripotent stem cells to a megakaryocyte-erythrocyte bi-potent progenitor population: an in vitro system for the production of platelets and red blood cells for transfusion medicine. In: University of Cambridge; 2018.

150. Shen Y, Nilsson SK. Bone, microenvironment and hematopoiesis. Curr Opin Hematol. 2012;19:250-5.

151. Jozaki T, Aoki K, Mizumoto H, Kajiwara T. In vitro reconstruction of a threedimensional mouse hematopoietic microenvironment in the pore of polyurethane foam. Cytotechnology. 2010;62:531-7.

152. Marx-Blümel L, Marx C, Weise F, Frey J, Perner B, Schlingloff G, Lindig N, Hampl J, Sonnemann J, Brauer D. Biomimetic reconstruction of the hematopoietic stem cell niche for in vitro amplification of human hematopoietic stem cells. PLoS One. 2020;15:e0234638.

153. Zhou D, Chen L, Ding J, Zhang X, Nie Z, Li X, Yang B, Xu T. A 3D engineered scaffold for hematopoietic progenitor/stem cell co-culture in vitro. Sci Rep. 2020;10:1-11.

154. Severn CE, Macedo H, Eagle MJ, Rooney P, Mantalaris A, Toye AM. Polyurethane scaffolds seeded with CD34+ cells maintain early stem cells whilst also facilitating prolonged egress of haematopoietic progenitors. Sci Rep. 2016;6:1-12.

155. Rowe RG, Daley GQ. Induced pluripotent stem cells in disease modelling and drug discovery. Nat Rev Genet. 2019;20:377-88.

156. Harding J, Mirochnitchenko O. Preclinical studies for induced pluripotent stem cell-based therapeutics. J Biol Chem. 2014;289:4585-93.

157. Bayley R, Ahmed F, Glen K, McCall M, Stacey A, Thomas R. The productivity limit of manufacturing blood cell therapy in scalable stirred bioreactors. J Tissue Eng Regen Med. 2018;12:e368-78.

158. Doss MX, Sachinidis A. Current challenges of iPSC-based disease modeling and therapeutic implications. Cells. 2019;8:403.

159. Volarevic V, Markovic BS, Gazdic M, Volarevic A, Jovicic N, Arsenijevic N, Armstrong L, Djonov V, Lako M, Stojkovic M. Ethical and safety issues of stem cell-based therapy. Int J Med Sci. 2018;15:36.

\section{Publisher's Note}

Springer Nature remains neutral with regard to jurisdictional claims in published maps and institutional affiliations. 